\title{
FINANCIAL INSTITUTIONS FOR ECONOMIC SUPPORT IN POST COVID ERA
}

\section{Irina Yarygina ${ }^{1}$}

DOI: https://doi.org/10.30525/978-9934-26-021-6-23

Abstract. Article deals with important issues within the international economic relations and displays the role of financial institutions as intermediaries that supply clients with financial instruments and contribute to sustainable economic development in the post covid period. The purpose of the article is to find out the features of bank activity and to develop recommendations for assessing financial techniques for supporting economic processes. Theoretical and empirical research methods are used to achieve the aim. Results reveal the features of variety of instruments, that can be implemented by public and private financial institutions in reaching the goals of improving leaving standards of population of developing countries and those, who are suffering from the contemporary economic turbulence, caused by global covid-19 pandemic. Originality/scientific novelty is determined by the implementation of the process of contemporary improving banking and its adaptation to the modern needs of high-quality service of economic entities in modern post covid economy. Practical value includes the formed methods and mechanisms of their implementation towards provision of the sustainable development of countries and their cooperation.

The results of the study provide a case for inter banking within developing economic in contemporary environment of post covid era. Recommendations can be taken into consideration while constructing economic and political approach to an international infrastructure.

It is strongly recommended to take into consideration the international experience and to introduce the required instruments to be successful within contemporary situation. Presented results of the study can benefit regulators

\footnotetext{
${ }^{1}$ Dr., Prof. Head of Programs, Professor,

Financial University under the Government of the Russian Federation,

Head of the Chair, MGIMO under the Ministry for Foreign Affairs of the Russian Federation ORCID: https://orcid.org/0000-0001-8684-1684
} 
and banks by providing new instruments for sustainable economic development.

\section{Introduction}

Actually, financial institutions play an important role in the process of economic development, especially in the post covid period. There is no denying the fact, that effective finance and relevant banking strategy depends on accurate assessment of common problems and a search for mutual solutions to improve quality of life of people, suffering from Covid-19 pandemic situations. From experience, fast liberation of financial-economic relationship in the period of after global turbulence leads to decline in strategic areas of national economy. At the same time, a slowdown of government regulation of key industrial areas leads to increase of bank speculations and increase the risk level of economic and financial environment. To find the way in turbulence is the main task for the governments, which has to use different vehicles, intergovernmental monetary and fiscal measures including.

Actually, economic development plays the key strategic role in banking and finance of developing countries. The analysis has proved that banks are able to support different sectors of economy and the growth of partnership by backing economic interest of countries and encouraging trade development that increases cooperation. Financial support for the least protected market participants - SMEs and entrepreneurs- driver and buffer of any economy creates favourable conditions for effective operations, employment, production of goods and value chains, that are under market demand.

At the same time, rating of the market demands of developing countries shows that long-term financing, project financing, syndicated loans and transparent information accelerate economic developments .Effective cooperation between entities are built on foundation of common interests and public support. Expertise from Central and Eastern Europe has proved that public support minimise shocks and promote progressive actions in restoration of economic relations. Another important lesson is the following: population is not concerned with prospect of any kind of reforms, but extremely interested in how they are going to be implemented in reality. Such kind of an experience is important in the post covid era and should be taken into consideration. 


\section{Formation of the problem}

The theory of fiscal federalism identifies main functions for the public sector: macroeconomic stabilization, income distribution and resource allocation (Oates, 1999). The problem of fiscal decentralization in developing countries are carefully studied by Fukasaku and de Mello, Manor, Crook and Manor (1998-1999), that tried to give reason to the restructuring of government and market functions. Some scholars within the public choice school consider that decentralization tends to increase health competition among jurisdictions (Brennan and Buchanan, 1980; Breton, 1989). Anyway, in globalized economy developing countries (Ahmad, 1997) require the mechanism of intergovernmental grants transfers. Thus, the intergovernmental financial institutions can contribute to it, supplying the country-members with unconditional, conditional and equalization grants (Brosio, 2000).

There is no denying the fact, that only international experience can provide useful methods for policy makers (Bird and Vaillancourt 1998), but the approach of laissez-faire or market fundamentalism has a week potential to solve most economic and social problems (Stiglitz, 1998). Market fundamentalism was popularized by George Soros in "The Crisis of Global Capitalism" (1998), which trusts in a free market mechanism. That is a privilege of a genius, but practice has proved the approach of J. E. Stiglitz, who criticized the IMF, advocating a set of policies, which is generally referred to the market fundamentalism, "based on an incorrect understanding of economic theory and as an inadequate interpretation of the historical data».

The correct understanding means reasonable regulation and cooperation in solving mutual problems and meeting new challenges. There is an on-going process of reengineering international cooperation within globalized economic environment. The speed of cooperation depends on macro and microeconomic factors, as well as participation in the global market, supply of the products and political support. Mutual aims of any government are linked with economic and social developments, as well as successful production, safe banking, financial stability and effective debt management, that is the main feature of post covid period of globalized economy. The goals can be reached by developing international cooperation and relevant financial institutions' support, that is extremely important in contemporary global environment. 


\section{Description of the research methods}

The study of financial institutions' role within BRICS was based on complex research methods, based on gathering and analyzing data, needed to answer the research goal.

Mostly used were qualitative and mixed methods. Within these categories, more specific approaches, including an array of options, case studies, self-reporting and surveys were applied. The mixed methods of research, that included contextual understanding like interviews or observations, were combined with facts and statistics, that contributed to the investigation of the subject on multiple levels, gaining different views and a comprehensive look at the research, An applied mixed methodology led us to the integration of different theories and ideas.

While carrying out the qualitative research, there was a goal to explore specific phenomena, not to prove a prediction, according to qualitative research methods. The assessment of interviews, focus groups and observation of main developments and contract arrangements were also used to collect data. Used qualitative methods provided rich, contextual explorations of the topic that is culturally meaningful.

\section{General approach to the banking support in post covid era}

Research proves that banks of emerging markets are in a race towards "fast profits" and cut down on traditional operations (project financing, loans, etc). Vast amount of operations is attributable to expatriation of capital into offshore zones. According to the World Bank, absence of banking support for economic development in ex-USSR countries lead to manufacturing decline of $65 \%$. However, in countries with government involvement and gradual market transformation - economy recovered faster (Kazakhstan, Uzbekistan). Use of reasonable government regulation of economy, as a whole, is a vital condition of development and formation of new approach to the realisation of commercial relationships and aids development of international banking. Effective cooperation between participants of BRICS countries is also influenced by the amount of government support given to economy during formation of market relationships. Under growing economic co-operation manufacturing feel pressure from their clients that require quality goods and services and from competition which are able to offer better quality at a lower price. Sensible 
regulation of inter-state relationships encourage economic co-operation. In its tern, creation of common legislation base which provides effective banking servicing of BRICS economy, will create stable foundation for collaboration. Establishment of essential conditions for interaction between credit institutions requires time and political power.

The analysis of current developments of emerging markets has proved, that financial institutions are able to support economy sectors during growth of partnership by backing economic interest of countries and encouraging trade development which increases cooperation. Banking support for the least protected market participants - SMEs, entrepreneurships - driver and buffer of any economy, will create favourable conditions for effective economic operations, creating employment, production of goods that are under market demand. Effective global cooperation of developing countries connected with necessary design of common banking support strategic developments. Consequently, creation of a reasonable international strategy is possible by using holistic analysis of economic demands of each partnercountry. Reality has shown that absence of economic forecasting in banking activity leads to negative consequences. For example, "tax holiday" policy, granted to banks by state of Brazil when dealing with foreign investors caused overproduction of cars, which created stagnation of number of economical segments. According to world practice, it is important to provide legal coverage for property of economic partners - a key business component taking into consideration specifics of each country. Formation of mutual economic strategy increases importance of banking intermediary, especially in the area of financial risk management, liquidity financing and management of financial capital. Country's economic development depends on the level of banking business involvement, attributable to customers and market partners.

Rating of market demands of developing countries shows that implementation of joint growth programme demands long-term financing, project financing, inclusive of syndicates and constant information flow in all segments of economy. Effective relationships between entities are built on foundation of common economic interests and governmental support. Expertise of many countries from Central and Eastern Europe has proved that public support and substantial banking activity desire to minimise change and promote progressive actions in restoration of economic ties. 
During the formation of a mutual economic strategy, it is important to consider the experience of CEE countries, which overcome the consequences of market reforms in the economy, which showed that countries are not concerned with prospect of banking reform but how they are going to be implemented in reality. In this regard, presence of objectivity in progressive actions towards available financial resources is very important. Governments support of entrepreneurs who are dealing in area of international trade, unification of banking activity and policies will create favourable conditions for economic cooperation. Growth of economic ties of partner-countries based on common values and development goals suggests a long-term strategic alliance of private credit institutions in the field of international trade, taking into account customer flexibility. Sound financial management, modernisation of banking technology will also contribute to the development of new markets. Support of the balance of interests of public and private structures, growing capacity of joint investment financing, strengthening the legal framework and improving the legal support of business - processes also contributes to the development of economic cooperation of economic entities. In addition, banks' activities supporting economic cooperation among BRICS countries should be transparent and accessible to the customer, regardless of the place of accreditation if their business activities executed in the economic environment of these countries. Currently, one of the important directions of banks - participants of international economic cooperation is a support programme of trade relations («Trade - Finance Promotion»), which assists customers in selecting contractors for International Cooperation. Currently, small and medium-sized enterprises of developing countries have to apply adverse cooperation schemes, including an advance payment for imports. In other cases, the completion of foreign trade contracts is prevented by excessive pricing conditions for underwriting and insurance payments. In this regard, using interstate status, a number of development banks can help to achieve favourable agreements with banks - exporters to improve the conditions for international cooperation.

One of the most important trends of banks is to provide payment guarantees to exporters, ensuring pre-export financing and cooperation with insurance companies. It seems appropriate for financial institutions in a post covid era to move towards the development of export - import activities of 
economic entities and to provide customers and their counterparties with a variety of banking services on the agreed «flexible» terms of cooperation. It can be provision of documentary operations, organisation of the bank syndicate to finance exporters / importers, financial market transactions, advising stakeholders, assist clients in calculating the limits for dealings with exporters and importers, confirmation of letters of credit and guarantees, issuance of Guarantees and counter-guarantees, use of interstate opportunities, taking into account documentary instruments, promissory notes, drafts, etc.

To meet demands of economic entities, financial institutions, mostly banks, are expedient to accept drafts drawn by exporter / importer, finance exporters against documentary letters of credit issued by reputable banks, to provide the agreed overdrafts, to ensure the implementation of credit lines for exporters / importers. Financing of drafts drawn by exporters or documents against acceptance as well as financing of goods supply in the initial stage of the implementation of contracts (for up to 180 days) and financing of importers/exporters, financing of the fulfilment of contractual obligations are also advisable. Actually, banks can accelerate provision of specialised services to business entities and convey clearing, maintain multicurrency accounts with the possibility of strengthening account liquidity, manage clients' short-term liquidity in the national currencies of developing countries, if they are not members of currency unions, manage accounts in national currencies through telecommunication systems and maintain the "escrow" accounts. Considerable attention of the banks and other financial institutions is to be payed to their corporate clients and their need of consultations on financial conditions of export-import contracts, currency regulation and currency control, including syndicated loans, hedge currency risks, currency arbitrage, trust operations on behalf of their clients.

An important component of creating a common economic space of the BRICS countries is a presence of special interstate deal insurance programme with involvement of government agencies for export insurance and guarantee of international operations. Specialised agencies are also able to promote multilateral cooperation for business partners.

Banks involvement in encouraging formation of multinational leasing companies with support of public institutions also promotes cooperation. An important area of international cooperation is discounted (governments - 
sponsored) financing of innovative and knowledge-intensive projects, as well as socio-economic programmes, such as environmental protection, infrastructure development, energy - supply and health programmes, etc. At the same time banks play an important role in engineering support of joint credit lines in order to ensure the economic benefits and enhance the living standards of countries, suffering from the post covid turbulence of national economies.

\section{Features of a relevant public support}

Actually, market participants assess the role of public institutions in post covid era: either it is a "pilot star" of the risky market or a bureaucratic vehicle, that enforces economic entities for non - profit behavior. What is it? History has given examples of a reasonable contribution of governments to economic progress. The experience of countries, bridged over transformations, pushes forward the idea of fruitful correlation of public and private entities, achieving economic development and profitable activity.

Actually, the government of the Russian Federation is keeping the way of economic supervision for the sake of improving standards of living of our people, even in the difficult period of pandemic situation and economic sanctions. Starting from the nineties of the XX century Russia entered the period of reforms. Within next fifteen years the market economy and its transparency has been growing, as well as standards of living have been improved as a result of a reasonable state participation in economic developments.

International experience has been approved by public authorities of the Russian Federation, that states as following:

1. Uncontrolled market can bring any country to social tension, polarization and unemployment. Based on international experience reasonable measures has contributed to the positive effect on price formation and structure of the economic development. The world economic crisis has also proved the hypothesis of the predominate role of the state in regulation of the market economy.

2. Market participants are doing their best in achieving short-term results, guided by "selfish" demand of profit, that sometimes contradict the socio - economic interest. Thus, it is impossible to back totally on the "wheels" of the market. 
3. Spontaneous change of the market economy is linked with financial discrepancies and accompanied by systemic and functional risks. To ensure social demand under these circumstances public institutions cannot, but support private entities to manage risks.

4. Public supervision does not mean involvement into activities of private entities. The goal is to challenge society interests, such as:

- economic growth, production increase, development of innovations, improvement of supply and demand structure;

- decrease of unemployment rate, support of price level;

- social responsibility: respect of regulation and profitable activity within the market environment.

There is no denying the fact, that the challenge of any government is the efficiency of macroeconomic supervision, provision of flexible rates for the economic growth, improvement of legislation, unification of business standards and increase of living standards.

Main problems to be solved by any government in contemporary situation is to insure economic development, stimulate public private partnership and provide reasonable regulation for economic entities and their activity.

Actually, to ensure positive economic developments Russian State Duma adopts laws on the market development and its supervision, which simplify the activities of business entities and make their activity transparent.

New challenges for public and private entities within the market are linked with responsibility of its activity: financing and insurance of export credits, production/promotion of goods and services, intellectual property and innovations.

Private entities of the Russian Federation take into consideration the international experience: special attention is paid to the early European capitalism in Germany, for example, has proved the effectiveness of a centralized control over prices, quality of goods and services, tax and rates regulation.

The historic "merry-go-round" produces lessons that should be put into local environment in accordance with its specificity. For example, there is a variety of proportion of monopolism and liberalism in different states and sometimes the necessity of state regulation of economy is considered to be doubtless. At the same time the succession of economic cycles shows that self-curing of the recession is impossible without public 
finance involvement. More than that, during the crisis the ties between the state and its entities deepens. Within the contemporary economic breakdown any public institution bears responsibility for its economic and social background. Public authorities have a vast range of instruments to influence the situation: taxation, monetary policy, legislation, etc. For example, the government of the Russian Federation pays great attention to implementation of efficient fiscal policy initiating the economic growth, such as: state expenses on social programs, maintenance of strategic development, reasonable taxation.

The main challenge of the government of Russia is to improve livingstandards of its population, backed by the economic growth. An important role in providing financial support play financial intermediaries - banks. At the same time an efficient banking strategy depends on the adequate estimation of economic peculiarity of its clients. Practice shows that speculative banking activity makes great problems: cutback of production, abrupt economic deregulation, etc. Being in pursuit of fast earning, private banks often cut down traditional banking and capital outflow to offshore zones starts to grow.

Reasonable regulation and supervision of the banking sector helps to reinstate economic background, that is reinforced be international cooperation.

At the same time, efficient international cooperation of private and public entities depends on instruments of economic and financial support.

There is no denying the fact, that market participants are under pressure of client's demand of high quality goods and services and the competitors are able to offer consumers goods of a better price and quality. Under these circumstances, equal treatment of all market participants and transparent determination of general principles of activities can push forward international cooperation. Unified legislative base, efficient bank support of economic entities creates steady background for regional cooperation within the integrated economic area.

However, formation of effective conditions for cooperation takes time. In general, underdeveloped countries are too enthusiastic and they underestimate the period of adoption to the level of the industrial growth. At the same time he points out the lack of a "political will" that usually spoils the situation. 
EBRD experts conclude, that, for example, the some of the CIS members are facing considerable decline of standards of living. This fact requires immediate action within the programs of international economic cooperation of the countries that have deep economic and cultural roots. Some of the post-soviet countries are suffering from bankruptcy, merges, acquisitions, lack of resources, etc. Solid banking support can help to recover. Regional programs of public support of non-protected participants of the market - small and medium enterprises (SME), for example, create favorable conditions for enterprises, capable to reach economic goals with public support. Unification of financial and banking rules helps to implement efficient support of SME's activity and effective international cooperation is connected with the unanimous international banking strategy. Putting it into action depends on a complex analysis of economic demands and challenges of market participants. The lack of economic estimation of the environmental peculiarities leads to harmful consequences. For example, "tax holidays" for foreign investors evoked an over-production of automobiles in Brasilia and caused stagnation of some branches of economy.

The analysis confirms also, that there is a stable tendency within the emerging financial markets: mergers of institutions, based on different motives. In general, the possibility of future profits is the most common motive for a merger. Firms will perform certain measures if it is the most profitable way of enhancing capacity, entering new product or geographic areas, acquiring new knowledge or skills, or reallocating assets into the control of the most efficient managers or owners. Pautler (2003) suggested motives for mergers and acquisitions include efficiencies, financial and tax benefits, market power effects, management greed, obtaining a good buy and stakeholder expropriation. These features should be taken into consideration by public institutions, while setting up rules and regulations for economic entities.

In terms of efficiencies firms and banking institutions of BRICS can combine their operations through mergers of firm's/bank's assets in an effort to reduce production costs, increase outputs, improve product quality, acquire new technology and/or produce new products. Aside from the new and improved products and output possibilities, mergers can create a market for corporate control, which can safeguard against inefficient management. This can be made possible by reallocating resources from firms with 
inefficient management to firms with efficient management especially in turbulent ages, that we are passing by. This helps to keep profits stable and reduce the risks. Another motive that Pautler (2003) refers to is stakeholder expropriation where shareholders gain at the expense of stakeholders. An example of this would be if a firm is looking to be acquired in order to escape financial problems or to back out of unfavorable labor contracts.

One of the basic motives for mergers is the consolidation of ownership. In advanced market economies this can be seen through takeovers in Central and Eastern Europe. There is no denying the fact, that takeovers help to solve corporate governance problems. More importantly for financiers Jensen and Ruback (1983) found that due to the merger the firms values actually increases in the process, suggesting that profits may increase afterwards.

An important factor of mergers is that they require a liquid capital market in order for the bidder to have access to large amounts of capital in the short term in order to manage it in common interests. The only one thing worthwhile mentioning: according to Rosen (2006) acquisitions and mergers announced in a hot merger market can end up having declines in the bidder's stock price in the long run. This can be tempting for managers to make bad acquisitions if they are rewarded with short-term performances.

\section{Conclusions}

The results of the study provide a case for inter banking within developing economic in contemporary environment of post covid era. Recommendations can be taken into consideration while constructing economic and political approach to an international infrastructure. Meeting the economic needs of population and mutual interests are certainly a step in the right direction of cooperation. However, the setting of needs depends on public strategy and relevant banking and finance. It is strongly recommended to take into consideration the international experience and to introduce the required instruments to be successful within contemporary situation.

Following the adoption of various declarations by partner - countries, more and more attention is focused on the objective need for infrastructure development. At the same time, the insufficient level of development of infrastructure, mainly transport and logistics, significantly hinders the expansion and deepening of trade and economic cooperation between countries. It is worthwhile drawing the attention to the fact, that official 
documents of developing countries indicate insufficient funding for such areas as infrastructure development and relevant banking. In addition to the above obstacles that hinder trade and economic cooperation in a multilateral format, problems in the field of customs cooperation, industrial development, and investment cooperation also need to be addressed. Despite the dominance of bilateral economic relations within contemporary framework, many of these problems should be solved jointly, in a combination of three, four partner - countries, depending on the degree of complexity of the problem and its significance for each country.

The development of electronic commerce and safe financial institutions' service is to be highlighted as one of the most promising solutions in the post covid era. The expediency of this has been emphasized repeatedly at high level meetings. At the present stage, the government-to-business (G2B) business model has become most common. In the nearest future, the introduction of other business models, such as B2B, B2C, C2C is also important, in order to ensure full cooperation and realization of the interests of all the main participants: government, business, financial institutions, consumers in each category of the population.

Presented results of the study can benefit regulators and banks by providing new instruments for economic developments in post covid period. Further novel concept introduced in this study relates to the usage of variety techniques in short-term and long-term relationship, backed by real requirements of legal entities.

The concept, presented in the study can be generalized in assessing trends and spheres of cooperation.

\section{References:}

1. Ahmad, E. (1997). Intergovernmental transfers - an international perspective, chapter 1 in Ahmad (ed.) Financing decentralized expenditures. An international comparison of grants. Cheltenham: Edward Elgar.

2. Bank for International Settlements. (2016). Basel: International convergence of capital measurement and capital standards: A revised framework.

3. Bird, R. \& Vaillancourt, F. (1998). Fiscal Decentralization in developing countries. Cambridge: Cambridge University Press.

4. Brennan, G. \& Buchanan, J.M. (1980). The power to tax: Foundations of a fiscal constitution. New York: Cambridge University Press.

5. Breton, A. (1989). The growth of competitive governments. Canadian Journal of Economics, vol. 22. 
6. Brosio, G. (2000). Decentralisation in Africa. The African Department. Washington DC.: International Monetary Fund.

7. Concept of cooperation between the Eurasian member - states in currency sphere from 22.06.2005 No. 220 (2012). Eurasian Economic Membership. Retrieved from: www.evrazes.com/docs/view/66

8. Crook, R.C., \& Manor, J. (1998) Democracy and decentralization in South Africa and West Africa. Participation, accountability and performance. Cambridge: Cambridge University Press.

9. Financial Stability Review. SA Reserve Bank. 2014. March. Retrieved from: www.reservebank.co.za

10. Fukasaku, K., \& L.de Mello Jr. (1999). Fiscal decentralisation in emerging economies. Governance Issues. Paris: OECD,Development Centre.

11. Jensen, M. C., \& Ruback, R. S. (1983). The market for corporate control: The scientific evidence. Journal of Financial economics, 11(1).

12. Manor, J., (1999). The political economy of democratic decentralization. Washington D.C.: The World Bank.

13. Oates, W. (1999). An essay on fiscal federalism. Journal of Economic Literature, vol. 37 , no. 3 .

14. Pautler, P. A. (2003). Evidence on mergers and acquisitions. AntitrustBull, 48.

15. Powell, R., \& Allen, D. E. (2009). Bank default risk in the US and UK. In Gregoriou (Ed.), Book on financial crisis. Chapman Hall.

16. Rockafellar, R. T., Uryasev, S., \& Zabarankin, M. (2006). Master funds in portfolio analysis with general deviation measures. Journal of Banking and Finance, 30(2).

17. Rosen, R. J. (2006). Merger Momentum and Investor Sentiment: The Stock Market Reaction to Merger Announcements. The Journal of Business, 79(2).

18. Soros, George (1998). The Crisis of Global Capitalism: The Crisis of Global Capitalism: Open Society Endangered. New York: PublicAffairs. ISBN 978-1-891620-27-0

19. Soros, George (2008). The New Paradigm for Financial Markets: The Credit Crisis of 2008 and What It Means. New York: Public Affairs. ISBN 978-1-58648-683-9

20. Standard \& Poor's (2016). Default, transition, and recovery: 2016 annual global corporate default study and rating transitions. Retrieved from: http://www.valuation.co.il/data/wacc/SnP-Default Transition and Recovery 2016.pdf

21. Stiglitz, Joseph E. The pact with the devil. Beppe Grillo's Friends interview autobiographical essay in acceptance of Nobel Memorial Prize in Economic Sciences, 2007.

22. Trade between South Africa and Russian Federation. January-December (2009-2013). Retrieved from: www.econsa.ru/tradesrf-sa.shtml 